\title{
HUBUNGAN ASUPAN GIZI MAKRO DENGAN PERKEMBANGAN MOTORIK KASAR PADA ANAK USIA 24-59 BULAN DI KELURAHAN DONGGALA, KOTA GORONTALO
}

\section{RELATIONSHIP BETWEEN MACRO NUTRITION INTAKE WITH THE DEVELOPMENT OF GROSS MOTOR IN CHILDREN AGE 24-59 MONTHS IN DONGGALA VILLAGE, GORONTALO CITY}

\author{
Mohammad Zulkarnain ${ }^{1 *}$, Ayu Lestari Sumitro ${ }^{2}$ \\ ${ }^{1}$ Program Studi Terapi Gigi Universitas Nahdlatul Ulama Gorontalo \\ ${ }^{2}$ Program Studi Ilmu Kesehatan Masyarakat Universitas Muhammadiyah Palu \\ Jl. Baypss, Tamalate, Kota Timur, Gorontalo
}

\begin{abstract}
ABSTRAK
Kemampuan motorik adalah kapasitas seseorang yang berkaitan dengan pelaksanaan dan peragaan suatu keterampilan yang dipelajari, sehingga akan memberi dampak pada pertumbuhan dan perkembangan anak. Kemampuan motorik lebih tepat merupakan kapasitas yang berkaitan dengan pelaksanaan dan peragaan keterampilan yang relatif melekat pada anak.Penelitian ini bertujuan untuk mengetahui hubungan asupan asupan karbohidrat dan lemak dengan perkembangan motorik kasar pada anak usia 2-5 tahun di Kelurahan Donggala Kota Gorontalo. Jenis penelitian ini bersifat analitik dengan desain cross sectional. Pengambilan sampel dilakukan secara total sampling dengan jumlah sampel 31 orang. Pengumpulan data dilakukan denan pengambilan data primer dan sekunder. Analisis data dilakukan dengan menggunakan uji chi-square. Hasil penelitian menunjukkan bahwa tidak ada hubungan bermakna antara asupan lemak $(\mathrm{p}=0,650)$ dengan perkembangan motorik kasar. Selain itu, hasil menunjukkan ada hubungan bermakna antara asupan lemak $(\mathrm{p}=0,044)$ dengan perkembangan motorik kasar.
\end{abstract}

Kata kunci: asupan karbohidrat; asupan lemak; perkembangan motorik kasar

\begin{abstract}
Motor skills are a person's capacity relaed to the implementation and demonstration of a learned skill, so that it will have an impact on children's growth and development. Motor skills are more precisely the capacity related to the implementation and demonstration of skills that are relatively inherent in childern. This study aims to determine the relationship between carbohydrate and fat intake and gross motor development in children aged 2-5 years in Donggala Village, Gorontalo City. This type of research is analytic with cross sectional design. Sampling was done by total sampling with a sample size of 31 people. Data collection was carried out by collecting primary and secondary data. Data analysis was performed using the chi-square test. The results showed that there was no significant relationship between fat intake $(p=0.650)$ and gross motor development. In addition, the results showed that there was significant relationship between fat intake $(p=0.044)$ and gross motor development.
\end{abstract}

Keywords: carbohydrate intake; fat intake; gross motor development

\section{Pendahuluan}

Masalah kekurangan gizi yang mendapat banyak perhatian akhir-akhir ini adalah masalah gizi kronis dalam bentuk anak pendek (stunting). Stunting didefenisikan sebagai indeks tinggi

\footnotetext{
${ }^{*}$ Penulis Korespondensi.

E-mail: mohammadzulkarnain828@gmail.com

Telp: +62-82293556208
}

badan menurut umur (TB/U) kurang dari minus dua standar deviasi (2SD) atau di bawah rata-rata standar yang ada dan severestunting didefenisikan kurang dari 3SD (Paramita, 2012).

Berdasarkan data WHO kasus anak usia prasekolah underweight di dunia sebesar 15,7\% dan anak usia prasekolah overweight sebanyak 6,6\% (WHO, 2013). Indeks Pembangunan Manusia (IPM) atau Human Development Index (HDI) Indonesia pada 2010 adalah 0,679. Hal ini 
memposisikan Indonesia pada peringkat 108 dari 187 negara. Tahun 2011, nilai HDI semakin merosot menjadi 0,628 , sehingga membawa Indonesia terpental ke rangking 124 dari 187 negara (UNDP 2011).

Data konsumsi pangan memberikan estimasi pada kuantitas setiap makanan yang disiapkan dikonsumsi oleh individu. Data konsumsi pangan sangat bervariasi dari satu negara ke negara dan bahkan dalam suatu negara karena variasi etnis, wilayah geografis, usia dan jenis kelamin. Menurut kerangka yang disusun oleh WHO, terjadinya kekurangan gizi, baik gizi kurang dan gizi buruk lebih dipengaruhi oleh beberapa faktor yakni, penyakit infeksi dan asupan makanan yang secara langsung berpengaruh terhadap kejadian kekurangan gizi, pola asuh serta pengetahuan ibu juga merupakan salah satu faktor yang secara tidak langsung dapat berpengaruh terhadap kekurangan gizi (Humaira H, 2016).

Global Nutrition Report menunjukan jumlah anak status gizi overweight dibawah 5 tahun mengalami peningkatan2. Diketahui anak status gizi overweight di ASIA tahun 2005 sebesar 15 juta, tahun 2010 sebesar 17 juta dan meningkat menjadi 20 juta pada tahun 20142 . Tren prevalensi gizi lebih anak 6-12 tahun Indonesia menunjukkan peningkatan. Diketahui prevalensi gizi lebih anak 6-12 tahun berdasarkan Riskesdas tahun 2010 sebesar 9,2\% dan 2013 sebesar 18,8\%. (Qamariyah B., 2018)

Pembentukan kualitas SDM yang optimal, baik sehat secara fisik maupun psikologis sangat bergantung dari proses tumbuh kembang pada usia dini. Perkembangan anak adalah segala perubahan yang terjadi pada anak meliputi seluruh perubahan yang terjadi pada anak meliputi seluruh perubahan, baik perubahan fisik, perkembangan kognitif, emosi maupun perkembangan psikososial yang terjadi dalam usia anak (infancytoddlerhood di usia 0-3 tahun, early childhood 3-6 tahun, dan middlechildhood 6-11 tahun). Masing-masing aspek tersebut memiliki tahapan-tahapan sendiri (Humaira $\mathrm{H}$, 2016).

Data dan Informasi Tahun 2014 (Profil Kesehatan Indonesia) dilaporkan bahwa status gizi anak balita menurut ketiga indeks berat badan menurut umur $(\mathrm{BB} / \mathrm{U})$, tinggi badan menurut umur $(\mathrm{TB} / \mathrm{U})$, dan berat badan menurut tinggi badan $(\mathrm{BB} / \mathrm{TB})$ terlihat prevalensi gizi buruk dan gizi kurang meningkat dari tahun 2007 ke tahun 2013 (Kemenkes RI, 2014).
Prevalensi balita sangat kurus secara nasional tahun 2013 masih tinggi yaitu 5,3\% terdapat penurunan dibandingkan tahun 2010 $(6,0 \%)$ dan tahun 2007 (6,2\%). Demikian pula halnya dengan prevalensi kurus sebesar 6,8\% juga menunjukkan adanya penurunan dari $7,3 \%$ (tahun 2010) dan 7,4\% (tahun 2007). Secara keseluruhan prevalensi anak balita kurus dan sangat menurun dari 13,6\% pada tahun 2007 menjadi $12,1 \%$ pada tahun 2013(Kemenkes RI, 2013).

Data Dinas Kesehatan (Dinkes) Provinsi Gorontalo pada tahun 2012 menunjukkan jumlah balita pendek atau "stunting" di daerah tersebut mencapai 26,83 persen. Ini setelah melakukan pemantauan status gizi terhadap 25 ribu balita.Angka tersebut mengalami penurunan dibanding tahun 2010 sebesar 38,06 persen dan tahun 2009 sebesar 41,15 persen Selain penderita gizi buruk, adanya balita pendek ini juga cukup mengkhawatirkan karena pertumbuhannya tidak optimal dibanding usia yang sebenarnya (Dinkes Prov. Gorontalo, 2012).

Derajat kesehatan masyarakat dipengaruhi oleh banyak faktor yang tidak hanya berasal dari sektor kesehatan seperti pelayanan kesehatan serta ketersediaan sarana dan prasarana kesehatan, melainkan juga dipengaruhi oleh faktor ekonomi, pendidikan, lingkungan sosial, keturunan dan faktor lainnya.Indikator-indikator yang dapat digunakan dalam menilai derajat kesehatan masyarakat adalah angka kematian (mortalitas), angka kesakitan (morbiditas) dan status gizi. gambaran situasi derajat kesehatan di Kota Gorontalo melalui angka kematian bayi (AKB), angka kematian balita (AKABA), angka kematian ibu (AKI), angka kesakitan beberapa penyakit, dan status gizi (Profil Dinkes Kota Gorontalo).

Salah satu penyebab rendahnya asupan zat gizi pada anak adalah kebiasaan makan.Sepertiga dari pemenuhan angka kecukupan gizi diperoleh dari makan pagi.Di Indonesia masih banyak anak yang tidak terbiasa ataupun melewatkan waktu sarapan, sedangkan yang sering sarapan mutu sarapannya masih rendah. Berdasarkan Riset Kesehatan Dasar 2010, 16,9\%-50\% anak usia sekolah dan remaja, serta rata-rata $31,2 \%$ orang dewasa tidak biasa sarapan. Anak sekolah mengkonsumsi minuman saat sarapan $(26,1 \%)$, seperti air putih susu, atau teh dan $44,6 \%$ mengkonsumsi sarapan berkualitas rendah3. Melewatkan sarapan ataupun konsumsi sarapan yang tidak memadai dapat menyebabkan defisit 
zat gizi. Ketidakcukupan zat gizi karena kehilangan nutrisi yang ditimbulkannya jarang dapat dipenuhi oleh konsumsi makanan di waktu lain. Sarapan dapat memberikan dampak positif pada status nutrisi (Sunarto, 2019).

Stimulasi yang diberikan pada anak yang telah mengikuti pendidikan di PAUD mempunyai perkembangan motorik kasar dan motorik halus yang baik, namun kemampuan perkembangan pada aspek bahasa-bicara dan sosialisasikemandirian masih kurang sesuai dengan anak usia 4-5 tahun, sehingga perlu diberikan stimulasi di rumah oleh ibu/keluarga maupun pengasuh. Perkembangan motorik kasar pada anak usia 4 tahun sangat menyenangikegiatan fisik. Perkembangan motorik halus pada anak usia 4 tahun sangat berkembang bahkan hampir sempurna. Anak 5 tahun telah mampu mengkoordinasikan gerakan visual motorik seperti mengkoordinasikan gerakan tangan, lengan dan tubuh secara bersama. Pada anak usia 4-5 tahun perkembangan yang paling menonjol yaitu ketrampilan motorik (Humaira H, 2016).

Perkembangan anak adalah segala perubahan yang terjadi padaa anak, dilihat dari berbagai aspek, antara lain misalnya pada aspek fisik (motorik). Perkembangan pengendalian gerakan tubuh melalui kegiatan yang terkoordinasi antara susunan saraf, otot, otak, dan spinal cord. Salah satu perkembangan yang penting adalah motorik kasar, yaitu gerakan tubuh yang menggunankan otot-otot besar atau sebagian besar seluruh anggota tubuh yang dipengaruhi oleh kematangan anak itu sendiri.

Penelitian yang dilakukan oleh (Sunarto, 2019) menunjukkan hasil bahwa ada hubungan yang signifikan antara asupan zat gizi makro (karbohidrat $\mathrm{p}=0,000$; protein $\mathrm{p}=0,000$; lemak $\mathrm{p}=0,000)$ dari sarapan dengan status gizi siswa di MTs Negeri 1 Kota Gorontalo.

Beberapa penelitian tentang penyelesaian masalah gizi dan pertumbuhan anak telah banyak dilakukan, baik ditingkat provinsi maupun tingkat kabupaten, namun yang terkait dengan Hubungan Asupan Zat Gizi Makro dengan Perkembangan Motorik Kasar Pada Anak Usia 24 - 60 Bulan belum banyak dilakukan dan dipublikasi. Hubungan Asupan Zat Gizi Makro dengan Perkembangan Motorik Kasar Pada Anak Usia 24 - 59 Bulan di Kelurahan Donggala Kecamatan Hulonthalangi Kota Gorontalo.

\section{Metode Penelitian}

Penelitian ini merupakan penelitian observasional analitik dengan pendekatan cross sectional study. Penelitian ini dilaksanakan di Kelurahan Donggala. Waktu penelitian selama 2 bulan yang mulai dari bulan Juni sampai bulan Juli2019. Populasi dalam penelitian ini adalah seluruh anak yang berada di Kelurahan Donggala sebanyak 35 orang. Teknik pengambilan sampel dengan teknik total sampling.

1. Pengolahan Data

a. Editing yaitu memeriksa kelengkapan, kejelasan makna jawaban konsistensi maupun kesalahan antar jawaban pada kousioner.

b. Coding yaitu memberikan kode-kode untuk memudahkan proses pengolahan data

c. Entry yaitu memasukkan data untuk diolah menggunakan komputer

d. Cleaning data yaitu data yang dimasukkan tidak luput dari kesalahan, yang disebabkan oleh kesalahan pemasukan data.

2. Analisis Data

a. Analisis univariat Analisis univariat dilakukan dari tiap variabel dari hasil penelitian berupa distribusi frekuensi dan presentase dari tiap variabel.

b. Analisis bivariat

Analisis bivariat dilakukan untuk melihat hubungan antara variabel independen dan variabel dependen.

c. Analisis Multivariat

Analisis multivariat adalah tehnik analisis dengan variabel bebas yang lebih dari satu. Metode ini digunakan untuk mengetahui besarnya hubungan antara beberapa variabel bebas secara bersamaan terhadap suatu variable.

\section{Pembahasan}

Berdasarkan hasil penelitian diketahui bahwa proporsi karakteristik berdasarkan jenis kelamin, yang paling tinggi pada laki-laki $67,7 \%$ dan terendah pada perempuan $32,3 \%$, berdasarkan umur, yang paling tinggi 4 tahun $41,9 \%$ dan terendah 5 tahun $12,9 \%$. Proporsi karakteristik berdasarkan pendidikan terakhir, yang paling tinggi pada tingkatan SMP 58,1\% dan terendah pada tingkat SD 19,7\%, berdasarkan pekerjaan, yang paling tinggi yang bekerja $100 \%$.

Hasil penelitian menunjukkan bahwa asupan zat gizi karbohidrat berdasarkan metode 
recall 24 jam lebih banyak asupan gizi normal dengan perkembangan motorik kasar kurang 58,3\% dibandingkan dengan motorik kasar baik $41,7 \%$ sedangkan asupan gizi defisit semuanya memiliki perkembangan motorik kasar kurang 100\%. Berdasarkan uji statistik Chi - Square diperoleh $\mathrm{p}$ value sabesar 0,044 , nilai ini lebih kecil dari $p$ value 0,05 , berarti ada hubungan Antara Asupan karbohidratdengan perkembangan motorik kasar anak usia 2-5 tahun.

Karbohidrat adalah sumber energi utama bagi manusia yang relatif murah. Karbohidrat terdiri dari 2 golongan yaitu karbohidrat sederhana dan karbohidrat kompleks. Karbohidrat sederhana merupakan gula dan merupakan bagian alami dari beberapa makanan seperti buah, sayur, dan susu. Karbohidrat kompleks merupakan tepung. Makanan tingi karbohidrat kompleks yaitu lentil, buncis, kacang kapri, kentang, jagung, ercis, nasi, pasta, grits, seral, tepung jagung, roti, dan oatmeal (Kowtaluk, 2001). Sebagian besar responden memperoleh asupan karbohidrat dari konsumsi nasi. Terdapat responden yang mengkonsumsi 300 gr nasi dalam 1 kali makan. Menurut penuturan responden, jika konsumsi nasi kurang maka akan membuat responden tidak kuat bekerja. Pekerjaan menyadap getah karet dapat dikatakan berat, terlebih bagi wanita (Santosa, 2004). Sebesar $40 \%$ waktu pekerja digunakan untuk berdiri menyadap pohon karet dan $60 \%$ waktu digunakan untuk berjalan mengambil getah karet serta memikul ember berisi getah karet (Almatsier, 2009).

Seseorang yang mengkonsumsi karbohidrat dalam jumlah berlebihan dapat menimbulkan kegemukan (Almatsier, 2009). Senada dengan hal tersebut, menurut Kowtaluk (2001), jumlah asupan zat gizi salah satunya adalah karbohidrat dapat menimbulkan kegemukan. Kegemukan dapat terjadi akibat konsumsi makanan yang melebihi angka kecukupan gizi (Adriani danWirjatmadi, 2012).

Penelitian sejenis telah banyak dilakukan sebelumnya. Penelitian yang dilakukan oleh Elnovriza (2009) menunjukkan bahwa antara asupan karbohidrat dengan status gizi tidak terdapat hubungan yang signifikan. Penelitian lainnya yang dilakukan oleh Atika, et al (2015) menunjukkan hasil bahwa tidak terdapat hubungan antara asupan karbohidrat dengan status gizi pada pelajar di SMP Negeri 13 Kota Manado.
Hal ini sejalan dengan penelitian sebelumnya dari Yulni, yang menyatakan terdapat hubungan antara asupan karbohidrat dengan status gizi berdasarkan IMT/U. Karbohidrat gizi utama penghasil energi, jika anak kekurangan asupan karbohidrat akan berakibat pada kekurangan energi. Kekurangan energi terjadi bila konsumsi energi melalui makanan kurang dari energi yang dikeluarkan. Tubuh akan mengalami keseimbangan energi negatif. Akibatnya, berat badan kurang dari berat badan seharusnya (ideal). Bila terjadi pada bayi dan anak-anak akan menghambat pertumbuhan dan pada orang dewasa penurunan berat badan dan kerusakan jaringan tubuh

Penelitian ini juga sejalan dengan penelitian sebelumnya dari Emalia (2015), asupan karbohidrat didapatkan p value 0,007 < 0,05 , ini berarti ada hubungan antara asupan karbohidrat dan status gizi. Kurang gizi akan menyebabkan kegagalan pertumbuhan fisik dan perkembangan kecerdasan, menurunkan daya tahan, meningkatkan kesakitan dan kematian.Status gizi seseorang tergantung dari tingkat konsumsi. Status gizi baik atau status gizi optimal terjadi bila tubuh memperoleh cukup zat gizi yang digunakan secara efisien, sehingga memungkinkan pertumbuhan fisik, perkembangan otak, kemampuan kerja dan kesehatan secara umum pada tingkat setinggi mungkin. Status gizi lebih terjadi bila tubuh memperoleh zat gizi dalam jumlah berlebihan, sehingga menimbulkan efek toksik atau membahayakan (Emalia, 2015).

Usia prasekolah merupakan periode keemasan (golden age) dalam proses perkembangan, yang artinya pada usia tersebut aspek kognitif, fisik, motorik, dan psikososial seorang anak berkembangan secara pesat. Salah satu aspek penting pada proses kembang ialah perkembangan motorik karena merupakan awal dari kecerdasan dan emosi sosialnya (Emalia, 2015).

Asupan zat gizi lemak berdasarkan metode recall 24 jam lebih banyak asupan gizi normal dengan perkembangan motorik kasar kurang 66,7\% dibandingkan dengan motorik kasar baik $33,3 \%$ sedangkan asupan gizi defisit dengan lebih banyak perkembangan motorik kasar kurang 68,0\% dibandingkan dengan perkembangan motorik kasar baik 33,3\%. Berdasarkan uji statistik Chi - Square diperoleh p value sabesar 0,650 , nilai ini lebih besar dari $p$ value 0,05 , berarti tidak ada hubungan antara 
asupan lemak perkembangan motorik kasar anak usia 2-5 tahun.

Pada penelitian ini sejalan dengan penelitian yang dilakukan Emalia (2015) menunjukkan bahwa tidak terdapat hubungan antara asupan lemak dengan status gizi dan perkembangan motorik kasar. Berdasarkan penemuan Burr, bahwa terdapat asam lemak yang esensial untuk tubuh, yaitu asam linoleat dan asam linolenat. Dikatakan esensial karena dibutuhkan tubuh, sedangkan tubuh tidak dapat mensintesisnya. Kedua jenis asam lemak ini dibutuhkan untuk pertumbuhan dan fungsi jaringan. Sejauh ini kekurangan dan kelebihan lemak tidak begitu diperhatikan untuk anak, karena belum ada pengaruh langsung pada perkembangannya, tetapi perlu diketahui hubungannya dengan perkembangan motorik anak. Sebagaimana diketahui balita memiliki kebutuhan gizi yang berbeda dari orang dewasa. Mereka butuh lebih banyak lemak dan lebih sedikit serat.

Salah satu komponen dari perkembangan motorik adalah perkembangan motorik kasar. Motorik kasar adalah gerakan tubuh yang menggunakan otot-otot besar atau sebagian besar atau seluruh anggota tubuh. Melalui keterampilan motorik yang baik, khususnya motorik kasar, anak dapat melakukan aktivitas mandirinya dengan baik, dapat melakukan gerakan-gerakan permainan seperti berlari, meloncat, memanjat, dan dapat melakukan keterampilan berolahraga dan keterampilan baris-berbaris yang diajarkan dalam pendidikan taman kanak-kanak yang diikutinya.Jika keterampilan motorik kasar anak kurang baik, tidak hanya pemenuhan kemandirian aktivitasnya yang terlambat, akan tetapi hal itu juga berdampak kepada perkembangan anak yang lain seperti halnya aktivitas sosial, kemampuan konsentrasi, dan kemampuan motor planning yang juga akan kurang baik.

Stimulasi adalah rangsangan rangsangan atau stimulus yang diberikan kepada anak oleh lingkungan sekitarnya, terutama orang tua agar anak bisa tumbuh dan berkembang dengan baik. Stimulasi tersebut diharapkan bisa memperbaiki perkembangan motorik agar anak dapat mengikuti pendidikan berikutnya. Bahaya penyebab terlambatnya perkembangan motorik, sebagian dapat dikendalikan dan sebagian lagi tidak. Kurangnya stimulasi berkaitan dengan kejadian terlambatnya motorik kasar. Hal ini sering disebabkan oleh kurangnya kesempatan anak untuk mempelajari keterampilan motorik, perlindungan orang tua yang berlebihan atau kurangnya motivasi anak untuk mempelajarinya dan kurangnya stimulasi (Emalia, 2015).

Lemak merupakan sumber energi paling padat, zat gizi ini menghasilkan 9 kalori untuk setiap gramnya yaitu 2,25 kali lebih besar energi yang dihasilkan oleh karbohidrat dan protein dalam jumlah yang sama. Lemak merupakan cadangan energi tubuh terbesar. Simpanan lemak tersebut berasal dari konsumsi salah satu atau kombinasi beberapa zat energi yaitu karbohidrat, lemak, dan protein (Almatsier, 2009). Sumber lemak berasal dari mentega, margarin, minyak tumbuh-tumbuhan (minyak kelapa, kelapa sawit, kacang tanah, kacang kedelai, dan jagung), daging, ikan, ayam, telur, susu, krim, keju, kacang-kacangan, bijibijan, alpukat, makanan yang dipanggang, dan makanan yang digoreng (Kowtaluk, 2001, dan Almatsier, 2009).

\section{Kesimpulan}

Hubungan asupan karbohidrat dan lemak dengan perkembangan motorik kasar berdasarkan metode recall 24 jam menunjukkan ada hubungan asupan karbohidrat $(\mathrm{p}$ value $=0,044)$, dan sedangkan asupan zat gizi lemak ( $\mathrm{p}$ value $=$ 0,650 ) menunjukkan tidak ada hubungan dengan perkembangan motorik kasar anak usia 2-5 tahun di Kelurahan Donggala Kota Gorontalo tahun 2019.

\section{Daftar Pustaka}

Almatsier, S. 2009. Prinsip Dasar Ilmu Gizi, Jakarta, PT Gramedia Utama. Andianto, B., 2010. Faktor yang Berhubungan dengan Produktivitas Kerja Tenaga Kerja di Bagian Pencetakan Kerupuk CV. Faisal Putra. Skripsi. Surabaya: Universitas Airlangga.

Adriani, M., and Wirjatmadi, B., 2012. Peranan Gizi dalam Siklus Kehidupan. Jakarta: Prenamedia Group.

Almatsier, S., 2009. Prinsip Dasar Ilmu Gizi. Jakarta: Gramedia Pustaka Utama.

Atika, W., Punuh, M. I., and Kapantow, N.H., 2015. Hubungan Antara Asupan Energi dan Zat Gizi Makro dengan Status Gizi pada Pelajar di SMP Negeri 13 Kota Manado. Jurnal Ilmiah Farmasi (Online), Vol. 4, No. 4. 
Doucet, E., and Tremblay, A., 1997. Food Intake, Energy Balance and Body Weight Control.EuropeanJournalofClinicalNutrition, Vol.51.

Hidayat, A. A. A. 2012. Pengantar Ilmu Keperawatan Anak 1. Jakarta : Salemba Medika.

Humaira H. dkk. 2016. Hubungan Status Gizi Dengan Perkembangan Psikomotorik Balita di Wilayah Kerja Puskesmas Lapai PadanTahun2014. Jurnal kesehatan andalas, 2016;5(2). http://jurnal.fk.unad.ac.id

Kementrian Kesehatan RI. 2010. Riset Kesehatan Dasar 2010, Jakarta, Badan Penelitian Dan Pengembangan Kesehatan Kementerian Kesehatan RI

Kementrian Kesehatan RI. 2013. Riset Kesehatan Dasar 2013, Jakarta, Badan Penelitian Dan
Pengembangan Kesehatan Kementerian Kesehatan.

Kementrian kesehatan RI 2015.Renstra Kementrian kesehatan tahun 2015-2019.

Sumiyati dkk. 2016. Stimulasi Perkembangan Anak Usia 4-5 Tahun. Jurnal LINK, 12920,2016,91-95. http://ejournal.poltekessmg.ac.id/oja /index.php/link

Soetjiningsih. 2012. Tumbuh Kembang Anak.Jakarta : EGC Supariasa

Sulpi, 2013.Hubungan ASI Eksklusif terhadap perkembangan motoric kasar bayi usia0-12 bulan di rumah sakit syarif hidayatullah tahun 2013.Skripsi. Fakultas kedokteran dan ilmukesehatan Universitas Syarif Hidayatullah, Jakarta 